\title{
A multiproxy approach to understanding the "enhanced" flux of organic matter through the oxygen-deficient waters of the Arabian Sea
}

\author{
Richard G. Keil, Jacquelyn A. Neibauer, Christina Biladeau, Kelsey van der Elst, and Allan H. Devol \\ School of Oceanography, Box 355351, University of Washington, Seattle, Washington 98195, USA \\ Correspondence to: Richard G. Keil (rickkeil@uw.edu)
}

Received: 13 July 2015 - Published in Biogeosciences Discuss.: 22 October 2015

Revised: 18 March 2016 - Accepted: 22 March 2016 - Published: 8 April 2016

\begin{abstract}
Free-drifting sediment net traps were deployed 14 times at depths between 80 and $500 \mathrm{~m}$ for 1-3 days each during the late monsoon-intermonsoon transition in the central Arabian Sea. Two locations (19.5 and $15.5^{\circ} \mathrm{N}$ ) were within the permanently oxygen-deficient zone (ODZ), and a third $\left(11^{\circ} \mathrm{N}\right)$ had a shallow and thin oxygen minimum. The secondary nitrite maximum, which serves as a tracer of the ODZ, thinned from $\sim 250 \mathrm{~m}$ thick at stations 19.5 and $15.5^{\circ} \mathrm{N}$ to $\sim 50 \mathrm{~m}$ thick at station $11^{\circ} \mathrm{N}$. Overall, organic carbon fluxes ranged from $13.2 \mathrm{~g} \mathrm{~m}^{2} \mathrm{yr}^{-1}$ at $80 \mathrm{~m}$ to a minimum of $1.1 \mathrm{~g} \mathrm{~m}^{2} \mathrm{yr}^{-1}$ at $500 \mathrm{~m}$. Fluxes at the more oxygenated $11^{\circ} \mathrm{N}$ station attenuate faster than within the permanent ODZ. Martin curve attenuation coefficients for 19.5 and $15.5^{\circ} \mathrm{N}$ are respectively 0.59 and 0.63 and for $11^{\circ} \mathrm{N}$ it is 0.98 . At least six potential mechanisms might explain why particles sinking through the ODZ are more effectively transferred to depth: (M1) oxygen effects, (M2) microbial loop efficiencies and chemoautotrophy, (M3) changes in zooplankton dynamics, (M4) additions of ballast that might sorb and protect organic matter from decay (M4a) or change sinking speeds (M4b), (M5) inputs of refractory organic matter and (M6) temperature effects. These mechanisms are intertwined, and they were explored using a combination of mineral (XPS) and organic matter characterizations of the sinking material, shipboard incubation experiments, and evaluations of existing literature. Direct evidence was found supporting an oxygen effect and/or changes in the efficiency of the microbial loop including the addition of chemoautotrophic carbon to the sinking flux in the upper $500 \mathrm{~m}$. Less direct evidence was found for the other potential mechanisms. A simple conceptual model consistent with our and other recent data suggests that the upper ODZ micro-
\end{abstract}

bial community determines the initial flux attenuation, and that zooplankton and sinking speed become more important deeper in the water column. The exact interplay between the various mechanisms remains to be further evaluated.

\section{Introduction}

Sinking particles are an important component of the biological pump. Once below the euphotic zone, organic matter and nutrients in sinking particles are removed from the biogeochemical processes of the upper ocean; the timescale of this sequestration depends on the depth to which the material sinks or is remineralized (Buesseler and Boyd, 2009). For sediment trap data, this is typically quantitated using either a power decay function (Martin et al., 1987) or by relating organic matter fluxes to ballast mineral flux (Armstrong et al., 2002). Using either approach, the decay function within oxygen-deficient zones (ODZs, waters with zero or unmeasurable oxygen; Jensen et al., 2011) is different - less decay - from that of the oxic portions of the ocean (Hartnett and Devol, 2003; Roullier et al., 2014; Van Mooy et al., 2002). That is, the relative proportion of organic matter that passes through ODZs is proportionally higher than that for oxic waters. There are many possible reasons for this, and currently they are poorly evaluated.

Potential mechanisms (M) that might cause organic carbon fluxes through ODZ waters to be less attenuated include those that are directly related to ODZs themselves: (M1) the possibility that anoxic degradation is sufficiently slower or less comprehensive relative to oxic carbon remineralization, (M2) the possibility that the microbial consortia in 
ODZ regions have a higher growth efficiency and incorporate chemoautotrophy, thus adding carbon to the flux, and (M3) zooplankton dynamics in ODZ regions might alter the flux attenuation in a variety of ways.

Mechanisms that are not necessarily specific to ODZ regions, but might simply be coincident, include (M4a) mineral protection where differences in bio- and lithogenic mineral inputs control the remineralization profile of sinking organic matter in the ocean, (M4b) changes in the sinking speed of particles due to differences in ballast, and (M5) inputs of recalcitrant organic matter, which could alter the flux attenuation. An additional potential mechanism (M6) is temperature. Marsay et al. (2015) suggest that temperature plays a role in determining the length scale of sinking particle remineralization, which could result in changes in apparent flux attenuation. Each of these potential mechanisms for enhanced flux through ODZ regions has merit, and they are briefly introduced below.

While the long-term (decade to millennia) importance of (M1) oxygen effects on organic matter preservation is well established (Arnarson and Keil, 2007; Hedges and Keil, 1995), the importance of oxygen over short time periods or during early diagenesis has been an extremely hard issue to address (Cowie and Hedges, 1992b). There seems to be an effect; Hartnett et al. (1998) suggested that the diminished oxygen exposure of ODZ sinking particles increases the efficiency with which they are transferred to deeper waters, and Van Mooy et al. (2002) observed direct oxygen effects in incubations of ODZ water from the eastern tropical North Pacific.

The microbial loop within an ODZ can influence the flux in a number of ways. If the community grows with a higher growth efficiency than oxic communities (M2a), then ODZ communities could produce more biomass per unit respiration. For example, if a dark aerobic community has a growth efficiency of $10 \%$ and a suboxic ODZ community has a growth efficiency of $20 \%$, then, for every unit of respiration, twice as much new biomass will result, and this will manifest itself as a change in the attenuation coefficient. This concept has been loosely explored by W. Naqvi (2014, personal communication). Additionally, the long-held assumption that heterotrophic respiration is the only significant biogeochemical process in the mesopelagic has been overturned by the discovery of abundant chemoautotrophic microorganisms (Dalsgaard et al., 2003; Kuypers et al., 2003). Thus, a subcomponent of M2 could be the (M2b) chemoautotrophic production of new organic matter in ODZs, which would add to the flux if it sinks (Close et al., 2014; Roland et al., 2008).

Zooplankton dynamics within the ODZ are complex and could alter the sinking flux in a variety of ways. When they migrate into the ODZ, zooplankton (M3a) deliver dissolved nutrients (Wishner et al., 2013) that can support chemoautotrophy and (M3b) create pulses of defecated material that is not subject to remineralization in shallower waters (Cavan et al., 2015). Both of these things would enhance the flux.
However, the ODZ is a harsh environment for a eukaryotic obligate aerobe, and if the ODZ hosts fewer zooplankton than an aerobic water column (Levin et al., 2015; Wishner et al., 2013) then it is logical to hypothesize that (M3c) the overall effect of zooplankton respiration will be less, which might in and of itself be enough to result in enhanced fluxes through the upper water column.

Minerals are a strong determinant on organic matter burial in sediments (Keil and Cowie, 1999; Keil and Mayer, 2014). How this impact is felt in the water column remains largely unconstrained. Inorganic material acts as a catalyst for particle formation, altering the flux of organic carbon (Lee et al., 2009). A possible mechanism linking mineral and enhanced flux would be that minerals can provide abundant points of interaction with organic matter, promoting aggregation and sorption (e.g., Passow and De La Rocha, 2006). (M4) Organic-mineral interactions might then protect the organic matter from remineralization, at least on the short timescale of sinking particles (Arnarson and Keil, 2005). Overall, organic carbon export might be enhanced both by increasing sinking rates and slowing degradation. Whether this mechanism could explain ODZ enhanced fluxes has not been explored.

Another potential factor linking carbon fluxes and mineral material is (M4b) sinking speed (Le Moigne et al., 2012). In both the Martin equation and the ballast model, sinking speed and remineralization rate combine to control the flux and attenuation. If, for some reason, ODZ regions have particles with enhanced sinking speeds, then lower attenuation per unit depth would result. Changes in sinking speed could result from changes in species composition or from changes in dust inputs, or the efficiency with which zooplankton and other community members package material into sinking particles (Cavan et al., 2015).

Lithogenic minerals might also impact sinking carbon by (M5) bringing refractory terrestrial organic matter with them (Burdige, 2007; Keil et al., 2004). To date, analyses of terrestrial carbon in sinking fluxes has largely been constrained to oxic water columns very close to land where the inputs are significant (Hedges et al., 1988).

Finally, the effect of temperature (M6) is to lengthen the depth scale of remineralization for colder (slower) situations (Matsumoto, 2007; Marsay et al., 2015). Since many ODZ regions are tropical or subtropical, temperature effects on particle degradation should result in higher attenuation (more degradation) in warm ODZ waters, but this appears not to be the case.

We evaluated these possible mechanisms using a combination of sediment trap and incubation studies, by measuring a variety of mineral and organic markers, and by comparing our data to recent literature for the Arabian Sea that uses complimentary analyses that help us address mechanisms where our data are insufficient. Direct analyses of our sediment trap materials included mineral surface area and surface-associated elemental compounds (using X-ray pho- 
toelectron spectroscopy), organic matter quantity and bulk ${ }^{13} \mathrm{C}$ and ${ }^{15} \mathrm{~N}$ isotopic compositions, and total amino acid and lignin compositions. Finally, targeted peptidomics was used to quantify key enzymes in the heterotrophic denitrification and the chemoautotrophic anammox pathways.

\section{Methods}

\subsection{Sample collection}

Surface-tethered, free-drifting sediment net traps (Peterson et al., 2005) were deployed from the $\mathrm{R} / \mathrm{V}$ Roger Revelle for periods of $12-48 \mathrm{~h}$. Sampling took place during the late monsoon-intermonsoon transition between 23 September and 6 October 2007 in the central Arabian Sea (Fig. 1). Three stations were occupied: stations 1 and 2 were located within the region previously documented as the permanent oxygen deficient zone (ODZ) (Naqvi, 1991), and station 3 was located at the edge of the permanent ODZ and had a much shallower and thinner ODZ (Fig. 1). Water column characteristics were evaluated at each station and at intermediate sites between stations based on water samples collected using $10 \mathrm{~L}$ Niskin bottles on a conductivity-temperaturedepth (CTD) rosette system. A Sea-Bird $\mathrm{O}_{2}$ sensor was calibrated to shipboard Winkler assays and a blank value equal to the steady-state value observed in the heart of the ODZ was subtracted from each measurement. This was done because oceanic ODZ regions including the Arabian Sea are now known to be functionally anoxic (Jensen et al., 2011; Thamdrup et al., 2012; Tiano et al., 2014; Ulloa et al., 2012). Nutrient concentrations have been reported previously (Bulow et al., 2010; Newell et al., 2011).

Three stations were occupied and a total of 14 sinking particle samples collected at depths from the thermocline to $500 \mathrm{~m}$ (Table 1). Two sizes of nets were used: a $2 \mathrm{~m}$ diameter net as originally described by Peterson et al. (2005), and a smaller $1.25 \mathrm{~m}$ diameter net (all dimensions scaled to the new diameter). The smaller nets were used for shallower sampling $(<200 \mathrm{~m})$ and the larger ones used at depths greater than $200 \mathrm{~m}$. Both nets used $53 \mu \mathrm{m}$ mesh on the cone and were closed using a brass messenger system. Nets were set either singly or in pairs (at two different depths) and tethered to the surface using polydac line, a string of surface floats, and a surface spar with radio transmitter and light beacon. The net traps were deployed open and were then closed using the messenger immediately prior to recovery. No poisons were used. Each trap sample was analyzed in duplicate.

Four additional samples were collected at depths $>1000 \mathrm{~m}$ by deploying the net traps as vertical nets and raising them through $100 \mathrm{~m}$ of the water column at $2 \mathrm{~m} \mathrm{~min}^{-1}$ before closing the nets using messengers (see Table 1). These samples were not used to evaluate fluxes but were analyzed for their organic components.

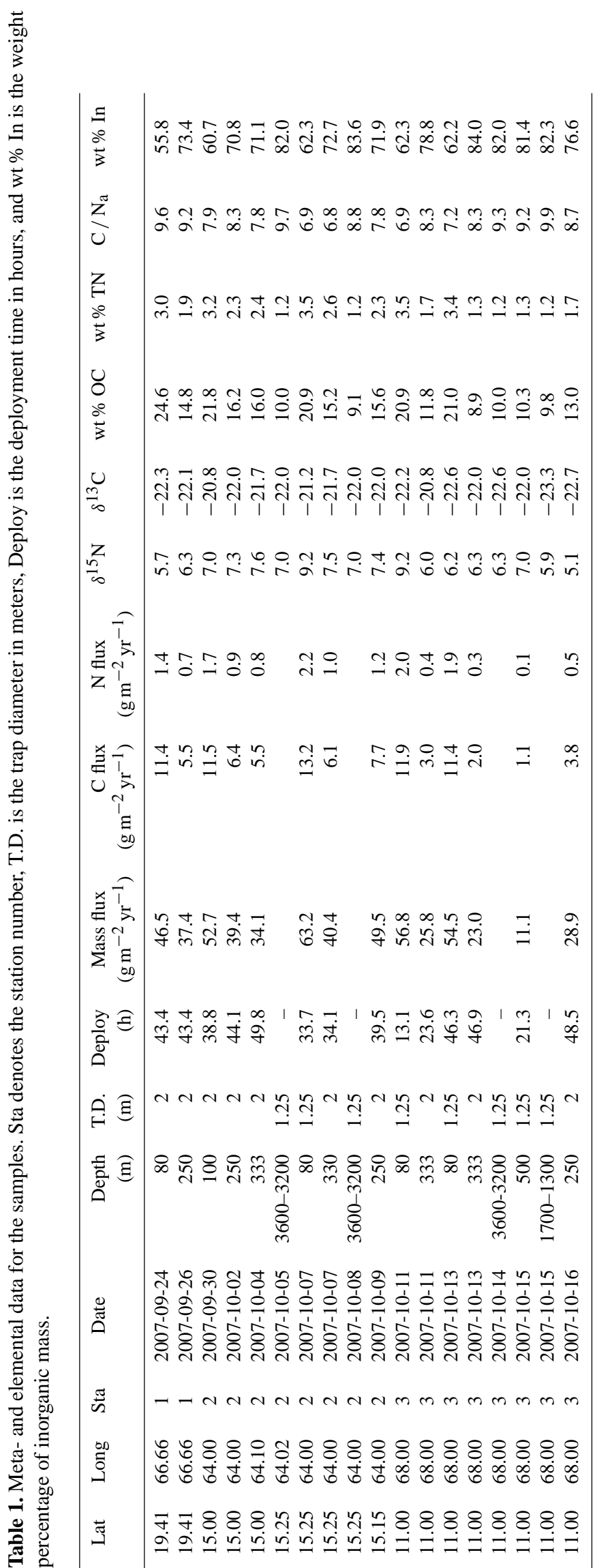

Biogeosciences, 13, 2077-2092, 2016 

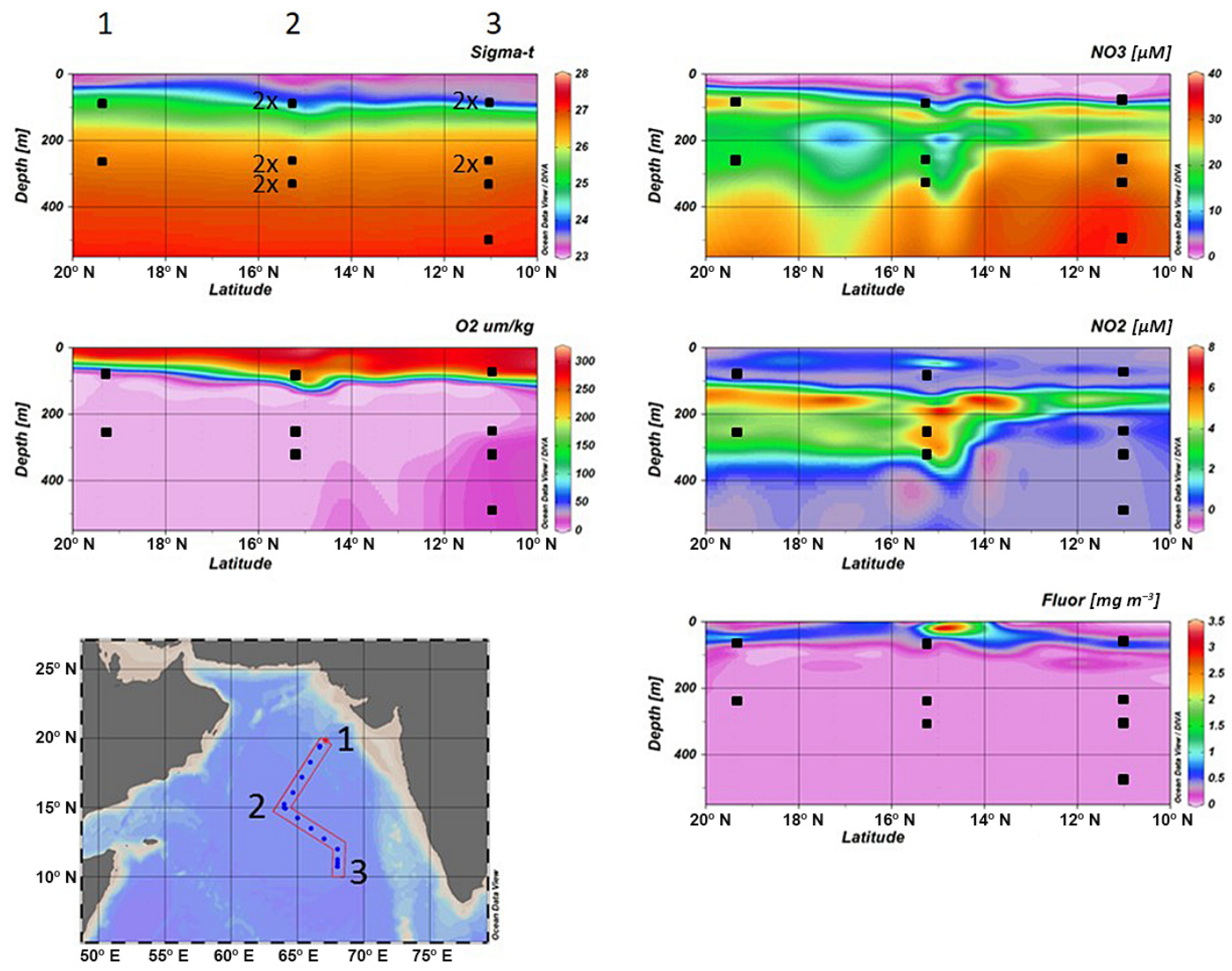

Figure 1. Spatial contours of water column parameters during the sediment trap deployments, clockwise from upper left: density, nitrate, nitrite, chlorophyll fluorescence, a map of the region including CTD stations (and with the trap deployment stations labeled 1-3), and oxygen. Squares in the upper left panel mark where sediment traps were deployed. A $2 \times$ denotes two traps deployed at these depths. Nutrient data previously reported by Bulow et al. (2010).

The $500 \mathrm{~mL}$ to $2 \mathrm{~L}$ samples from sediment trap collection cups were transferred to polypropylene bottles, swimmers (which were very minimal in these oxygen-poor waters) were picked out, and the sample was frozen and transported to the lab at the University of Washington. In the lab samples were thawed and spun at $15000 \times g$ in $\sim 200 \mathrm{~mL}$ aliquots. Resultant pellets of sinking material were separated from the liquid, combined, weighed wet, freeze-dried, and weighed again. After a small salt correction the dry weight was used to calculate the mass flux.

\subsection{Elemental, XPS, amino acid and lignin analyses}

Elemental analyses for particulate carbon, nitrogen quantities and ${ }^{13} \mathrm{C}$ and ${ }^{15} \mathrm{~N}$ isotopic compositions were carried out at the U.C. Davis Stable Isotope Facility (http: //stableisotopefacility.ucdavis.edu) on both raw and acidified samples. Acidification was achieved via direct application of $1 \mathrm{M} \mathrm{HCl}$ using the technique described in Kennedy et al. (2005).

XPS surface characterizations were done at the University of Washington's Surface Analysis Recharge
Center (http://www.nb.engr.washington.edu/content/ surface-analysis-recharge-center-sarc) with Surface Science Instruments (SSI) S- and M-probes as described in Arnarson and Keil (2001). Analyses were made in duplicate with an average spot size of $\sim 200 \mu \mathrm{m}$ and a theoretical average scanning depth into the sample matrix of $\sim 20 \mathrm{~nm}$. The measured atom percent of each detected element was multiplied by its molecular weight and then weight percentages were calculated. We assume that hydrogen has a negligible contribution on a weight basis (hydrogen is the only element that the XPS cannot see; the detection limits for most other elements are $\sim 1$ at. \%; Arnarson and Keil, 2001).

Amino acids were liberated via acid digestion (Cowie and Hedges, 1992a) and quantified by liquid chromatographytriple quadrupole mass spectrometry using an isotope pairing technique similar to that of Piraud et al. (2005). Briefly, samples were hydrolyzed in $6 \mathrm{M} \mathrm{HCl}$ via programmed microwave assistance in a MARS 5 microwave system (CEM Corp), brought to dryness in a CentriVap system (LabConCo), resuspended in Milli-Q water and filtered through a $13 \mathrm{~mm} 0.2 \mu \mathrm{m}$ nylon membrane (Acrodisc, PALL Life Sciences). Isotopically labeled amino acids (Cambridge Iso- 
topes) were then added. Samples were run on an Agilent Poroshell 120 SB-C18 column $(100 \mathrm{~mm})$ with solvents of (a) Milli-Q containing $0.05 \%$ heptafluorobutyric acid $(v / v)$ and (b) acetonitrile containing $0.05 \%$ heptafluorobutyric acid $(v / v)$. A six-point standard curve plus blanks was run each day, and the NIST amino acid standard mixture with added isotopically labeled amino acids was run with every set of samples (e.g., every day) as a test of the accuracy of the liquid chromatograph-mass spectrometer. The multiple reaction monitoring parameters used for identification are shown in Supplement Table S1.

Lignin phenols were analyzed by microwave-assisted cupric oxide oxidation (Goni and Montgomery, 2000) followed by trimethylsilyl derivatization and capillary gas chromatography-mass spectrometry (Keil et al., 2011). Yields of cinnamyl "C", syringyl "S" and vanillyl "V" phenols were used to evaluate vascular plant sources of the sedimentary organic bulk mixture. These phenol yields are conventionally represented as lambda $(\Lambda 8 ; \mathrm{mg}$ per $100 \mathrm{mg}$ of organic carbon) and $\Sigma 8$ (the sum of the eight major phenols normalized to $10 \mathrm{~g}$ of bulk sample).

\subsection{Targeted peptidomics}

Peptides specifically diagnostic of proteins of interest were identified using a targeted peptidomics approach (Bertrand et al., 2013). Briefly, peptides were extracted as per Bridoux et al. (2015), where samples were suspended in a lysis buffer ( $7 \mathrm{M}$ urea, $2 \mathrm{M}$ thiourea, carrier ampholytes $(2 \% v / v, \mathrm{pH}$ 3-10), dithiothreitol (DTT, $1 \% w / v$ ), and protease inhibitor cocktail $(1 \% v / v))$ and lysed while ice cold using sonication, precipitated with ice-cold $20 \%$ trichloroacetic acid in acetone (TCA / acetone, 1:5 v/v) for $\sim 12 \mathrm{~h}$ at $-20^{\circ} \mathrm{C}$ and then enzymatically digested with trypsin following a protocol adapted from Nunn et al. (2010). The resulting tryptic peptides were desalted using a macro-spin $\mathrm{C}_{18}$ column (NestGroup), resuspended in $20 \mu \mathrm{L}$ of $5 \%$ acetonitrile $(\mathrm{ACN}) / 0.1 \%$ formic acid and introduced into a Waters Xevo TQ-S triple quadrupole mass spectrometer via a Waters Acquity nanoUPLC. Peptides of interest were separated on a Waters HSS T3 $150 \mathrm{~mm}$ column with solvents of water with $0.1 \%$ formic acid (a) and acetonitrile with $0.1 \%$ formic acid (b). Spectra were evaluated using Skyline software https://skyline.gs.washington.edu. Target peptides and their associated proteins are identified in Table S2.

\subsection{Incubation studies}

Toward the end of the cruise, sinking particles collected from $80 \mathrm{~m}$ depth at station 3 were incubated in large trilaminate bags (Ward et al., 2008, 2009). The bags were vacuumemptied and then filled with water from a Nisken bottle as per Ward et al. (2008), during which time a small syringe containing a slurry of sinking particles collected from the net traps was injected into the bags through a three-way valve (see also Chang et al., 2014). Injection volumes were kept constant but the quantities of added organic matter were not measured. Oxygen was added to each bag using a syringe filled with $\mathrm{O}_{2}$-saturated seawater from $80 \mathrm{~m}$ depth. The exact oxygen addition was not known until it was measured using a flow-through optode system (Ocean Optics). Bags were sampled periodically for nutrients, $\mathrm{pH}$, alkalinity and oxygen content. The $\mathrm{pH}$, alkalinity and nutrient data were used to calculate total dissolved inorganic carbon (DIC) assuming that all other sources of variability in alkalinity were negligible (Van Mooy et al., 2002). Changes in total DIC compared to the initial time point were used to evaluate respiration. In one experiment, dust collected from the Sahara (collected by R. G. Keil in Tunisia) was added to the bags at quantities of $\sim 100 \mu \mathrm{g} \mathrm{L}^{-1}$. The dust had previously been screened to remove particles larger than $100 \mu \mathrm{m}$ and had been slowly combusted to $400{ }^{\circ} \mathrm{C}$ in an effort to clean any existing organic matter off the mineral surfaces (Arnarson and Keil, 2001). The dust was suspended in seawater from the same depth as the net trap for $24 \mathrm{~h}$ before being added to the incubation bags, and was vigorously vortexed immediately prior to being injected into the bag.

\section{Results}

Based on the CTD casts and nutrient analyses for the three main stations and the seven additional CTD-only stations, the water column conditions changed along the transect. The area around station $2\left(15^{\circ} \mathrm{N}\right)$ had the highest standing stock of chlorophyll, and the region around station $3\left(11^{\circ} \mathrm{N}\right)$ had the thinnest ODZ (Fig. 1). The secondary nitrite maximum, which can be used as a tracer of the functionally anoxic zone, thinned from $\sim 250 \mathrm{~m}$ thick at stations 1 and 2 to $\sim 50 \mathrm{~m}$ thick at station 3 (Fig. 1).

Sediment net traps have the advantage of a large collection area relative to other sediment trap types, allowing for rapid collection of large amounts of settling material in short periods of time (Peterson et al., 2005). Total mass fluxes trapped by the drifting nets ranged from $63.2 \mathrm{~g} \mathrm{~m}^{2} \mathrm{yr}^{-1}$ at station 2, $80 \mathrm{~m}$ depth, to a minimum of $11.1 \mathrm{~g} \mathrm{~m}^{2} \mathrm{yr}^{-1}$ at station 3, $500 \mathrm{~m}$ depth (Table 1). Organic carbon and total nitrogen fluxes attenuated similarly to each other with depth (Fig. 2), and the fluxes at station 3 attenuate faster than at the other two stations, an observation enhanced after normalizing the fluxes to that at $80 \mathrm{~m}$ depth (the base of the euphotic zone) (Fig. 2c). Martin curve attenuation coefficients for 19.5 and $15.5^{\circ} \mathrm{N}$ are 0.59 and 0.63 , and 0.98 for $11^{\circ} \mathrm{N}$. The differences in attenuation coefficients equate to degradation rate differences of $\sim 35-50 \%$ assuming a constant sinking flux.

Organic carbon contents range from 8.9 to $24.6 \mathrm{wt} \%$ organic carbon, with the minimal values generally associated with the deeper samples (Table 1, Fig. 2). Organic carbon is lost from the sinking particles faster (shallower) at station 3 than the other two stations (Fig. 2). Similar trends are ob- 

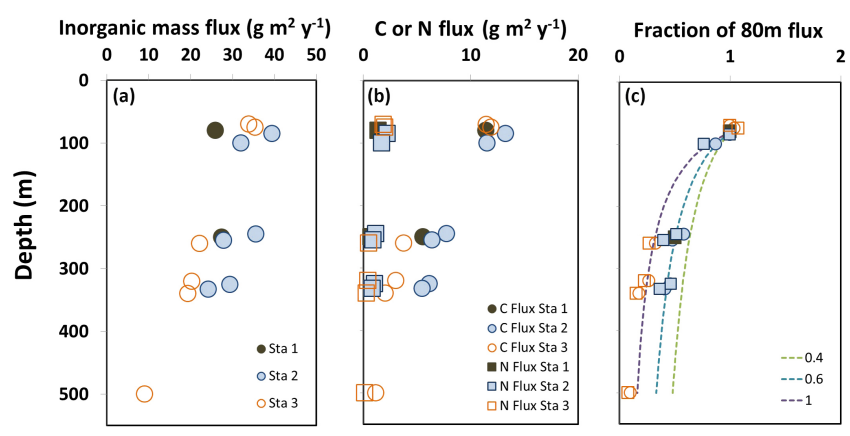

Figure 2. Sediment trap fluxes for inorganic material (a), organic $\mathrm{C}$ and total $\mathrm{N}$ (b) and the fraction of the $80 \mathrm{~m}$ organic $\mathrm{C}$ or total $\mathrm{N}$ flux observed in deeper traps. Dashed lines in (c) denote Martin curves with attenuation coefficients between 0.4 and 1.0. At stations 2 and 3 multiple traps were deployed at nearly the same depth. Individual symbols represent the average of duplicate analyses of each trap sample. That is, replication is shown at the "trap" level, and the variation within duplicate analyses of an individual trap sample is encapsulated within the size of the symbol.

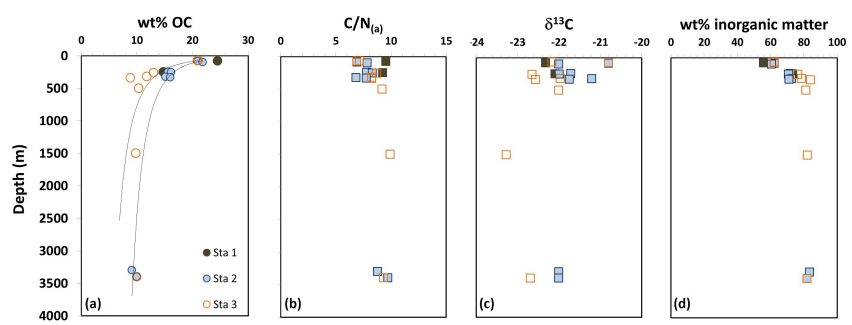

Figure 3. Weight percent organic carbon (a), atomic ratios of organic carbon to total nitrogen (b), the stable carbon isotopic composition of the bulk organic matter (c) and the percentage of inorganic material (d). Power functions in the left-most panel were added to aid the eye in discerning possible differences between the three stations. Samples from deeper than $500 \mathrm{~m}$ were collected via slow net haul (see Methods section).

served for the total nitrogen content of the samples (Table 1). The $\mathrm{C}_{\text {org }}: \mathrm{N}$ ratio of the sinking particles is close to Redfield at the surface and increases to $\sim 9$ with depth (Fig. 3). The exception to this is station 1 , where the $\mathrm{C}: \mathrm{N}$ ratios are $\sim 9$ at the two surface depths. Stable carbon isotopic compositions of the sinking particle range from -20.8 to $-23.4 \%$, with those from station 2 being enriched relative to station 3 (Fig. 2).

Total carbon on the surfaces of the particles, as measured by XPS, is highest (60-72 at. \%) in the $80 \mathrm{~m}$ samples and decreases to $\sim 50 \%$ in the particles collected deeper (Fig. 4a). The only other elements detected by XPS were oxygen, silicon, calcium and nitrogen. As opposed to carbon, the proportions of oxygen, silicon and calcium are enriched with depth (Fig. 4b-d). Combining the bulk elemental data with that collected by XPS allows for evaluation of the organic carbon "placement" within the sinking particles via

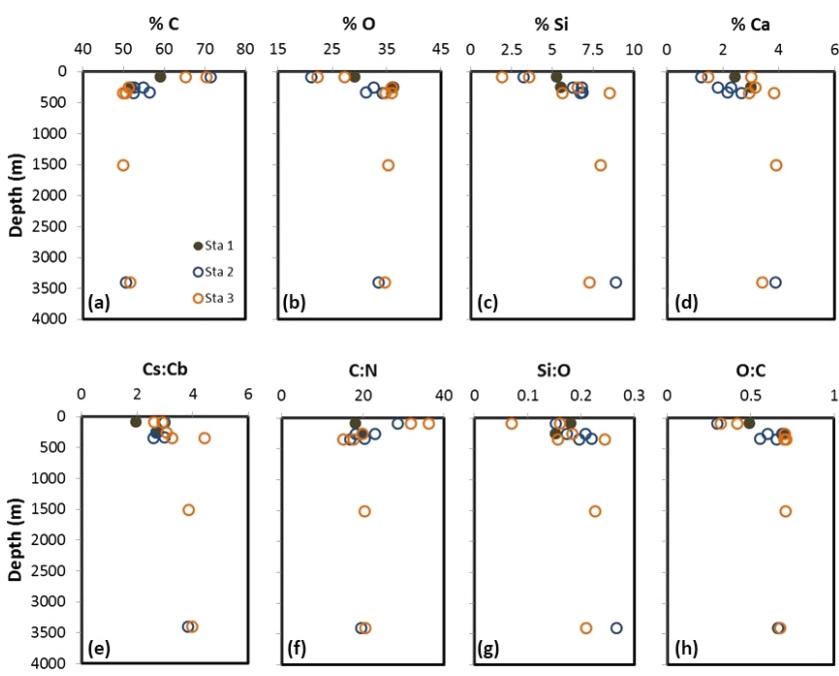

Figure 4. Atom percentages of different elements identified by XPS on the surfaces of the sinking particles: (a) carbon, (b) oxygen, (c) silicon, and (d) calcium. (e) Weight percentage ratio of carbon on the surface of the particles to bulk carbon measured by elemental analysis, (f) atomic $\mathrm{C}: \mathrm{N}$ ratio of carbon and nitrogen at the surface, and (g) atomic silica: oxygen ratio, (h) atomic oxygen:carbon ratio. (Color scheme for symbols same as in Fig. 3.)

the $\mathrm{OC}_{\mathrm{on}}$ the surface $: \mathrm{OC}_{\text {bulk }}$ ratio (Arnarson and Keil, 2001). Values of this ratio are between 2 and 3 in the surface waters and rise to 4-6 with depth (Fig. 4e). The ratio is higher for the deeper samples at station 3 than at the other two stations (Fig. 4).

Using the Redfield ratio for organic matter, as modified by Hedges et al. (2002), the amount of inorganic mass was calculated as the difference between the mass flux and the total organic matter flux (Table 1). Settling particles range from 55 to $84 \%$ inorganic matter. The inorganic matter flux ranges from 9 to $39 \mathrm{~g} \mathrm{~m}^{2} \mathrm{yr}^{-1}$ and decreases with depth (Fig. 2a). Station 2 has the largest inorganic mass flux, coincident with the highest chlorophyll levels.

Amino acid abundances and compositions change as a function of depth but show little variation with station (Fig. 5). The mole percent of non-protein amino acids, which is an indicator of the diagenetic state of the amino acid pool (Cowie and Hedges, 1994), is less than 1 at the surface and less than 3 in the deeper samples (Fig. 5a). The amino acid degradation index (DI), as calculated using the formulation of Dauwe et al. (1999), ranges from 0.25 to 1.0 and represents relatively "fresh" organic matter (Table A4). At stations 2 and 3 the DI decreases with depth (Fig. 5b).

For the sediment trap samples, the copper oxide yield of lignin phenols is $<2 \mathrm{mg} \mathrm{gdw}^{-1}$ (Table A5) and is less at the deeper samples relative to the $80 \mathrm{~m}$ samples (Fig. 5c). When normalized to the total amount of organic carbon present, there is an enhancement of lignin at station 1 relative to the 


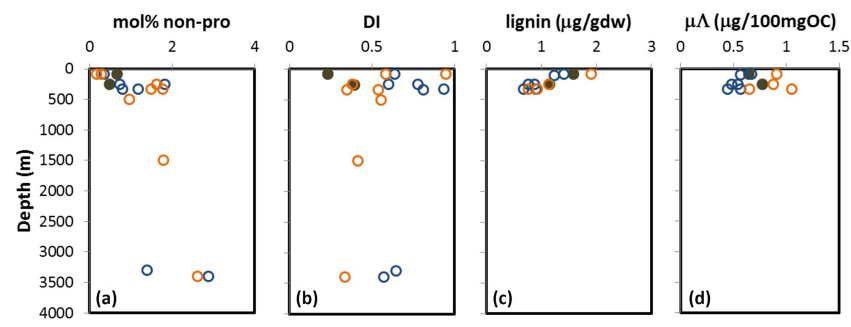

Figure 5. (a) Mole percentage of non-protein amino acids, (b) amino acid degradation index, (c) lignin phenol yield per gram dry weight of sinking material, and (d) $\mu \Lambda$, the lignin yield in micrograms per $100 \mathrm{mg}$ organic carbon. (Color scheme for symbols same as in Fig. 3.)

other two stations (Fig. 5d). There was not enough sample material in the deep net tows for lignin analyses.

Target peptide quantities were typically below $400 \mathrm{fg} \mathrm{mgdw}^{-1}$ except for histone, which peaked at $17000 \mathrm{fg} \mathrm{mgdw}^{-1}$ (Fig. 6). In general, target peptide quantifications decreased with depth and with oxygen concentration, again except for histone and $\mathrm{ABC}$ transporter proteins, which showed no negative relationship against oxygen (Fig. 6).

Incubation experiments conducted using sinking particles from station 3, $80 \mathrm{~m}$ depth, showed inhibition of DIC production when either oxygen concentrations were low (Fig. 7a) or when dust was added to the collapsible incubation bags (Fig. 7b).

\section{Discussion}

Understanding carbon fluxes through ODZs is critical for ascertaining and predicting how oceanic systems have and will respond to climate change. The size of ODZs is exceptionally sensitive to climate change and variability; it only takes a $1 \%$ reduction of the ocean's $\mathrm{O}_{2}$ content to double the size of the ODZs (Deutsch et al., 2011), and some climate model simulations predict substantially larger perturbations to the oceanic $\mathrm{O}_{2}$ reservoir $(\sim 5 \%)$ within this century (Bopp et al., 2013). While ODZs occupy a small percentage of the ocean ( $<1 \%$ by volume) (Paulmier and Ruiz-Pino, 2009; Stramma et al., 2012), they account for $30-50 \%$ of the oceanic loss of $\mathrm{N}$ as $\mathrm{N}_{2}$ (DeVries et al., 2012), driving $\mathrm{N}$ limitation of ecosystem productivity over large swaths of the photic zone, and far from the ODZs themselves.

There are three major permanent ODZ regions: the eastern tropical North and South Pacific (ETNP, ETSP) and the Arabian Sea. Unfortunately, to date there have been few systematic evaluations of sinking particles within and outside these ODZ regions. The simplest way to evaluate different regions is to take the available data and fit it to the Martin curve (Martin et al., 1987). While this power fit to data does not have a direct ecological relevance for the "attenu- ation" term, it does serve the purpose of providing a convenient single number that can be compared between regions. In the original "Martin curve" paper, three sets of drifting sediment traps were deployed within an ODZ region, while the other six locations were all well oxygenated (Martin et al., 1987). The attenuation coefficients for the ODZ regions averaged $0.59 \pm 0.24$, whereas the oxygenated values averaged $0.89 \pm 0.06$. The authors did not focus on the causes of this regional variability.

In the ETNP, Van Mooy et al. (2002) observed low particle attenuation in ODZ at a station north of Martin's and calculated an attenuation coefficient of 0.40 . Using benthic lander data, flux attenuation along the Washington and Mexican margins are thought to differ, with the ODZ waters off Mexico having an average attenuation coefficient of 0.36 while the oxic Washington margin has an attenuation coefficient of 0.93 (Devol and Hartnett, 2001; Hartnett and Devol, 2003). In these studies, differences in attenuation were interpreted as oxygen effects on microbial degradation of the sinking material.

In the ETSP, systematic evaluations beyond Martin et al. (1987) are few. Levin et al. (2002) evaluated benthic system ecology and energy flow at $30^{\circ} \mathrm{S}$ over a 2 -year period and suggested that oxygenation events were strongly associated with more carbon remineralization of the sinking flux (which they did not directly evaluate). That is, they found indirect evidence that the attenuation parameter was higher under the more oxic conditions. Using benthic data in a manner similar to that of Devol and Hartnett (2001), Dale et al. (2015) suggested that the attenuation in the ETSP was only slightly attenuated (Martin coefficient of 0.54 ) and that the impact on the sediment was greater than that in the water column. Deep sediment traps show variation suggestive of changes in fluxes of lithogenic material (Hebbeln et al., 2000; Marchant et al., 2004), but the data are not complete enough to evaluate attenuation.

In the Arabian Sea there is a great deal of flux data. Along the western margin, Lee et al. (1998) combined sediment trap, primary production and ${ }^{234} \mathrm{Th}$ data to evaluate particle fluxes. They did not fit their data to a Martin curve, but all the information needed is available. Their attenuation values range from 0.10 to 0.49 within in the ODZ and was 0.96 at their oxygenated $10^{\circ} \mathrm{N}$ site. Roullier et al. (2014) used a visual profiler to evaluate sinking particles and calculated an attenuation coefficient of 0.22 , suggesting little attenuation within the ODZ. Similar results have been observed in many other studies and for a variety of specific organic compounds (e.g., Haake et al., 1992). Our data are in accord; the attenuation of the organic matter flux (e.g., Fig. 2) is different between the three stations, with the one that is most oxic and furthest south (station 3) having the most attenuated flux.

Thus, it appears to be a truism that ODZ regions "allow" proportionally more organic material to transit to the deep sea relative to oxygenated systems. The mechanisms that might cause this remain poorly evaluated and potentially include 

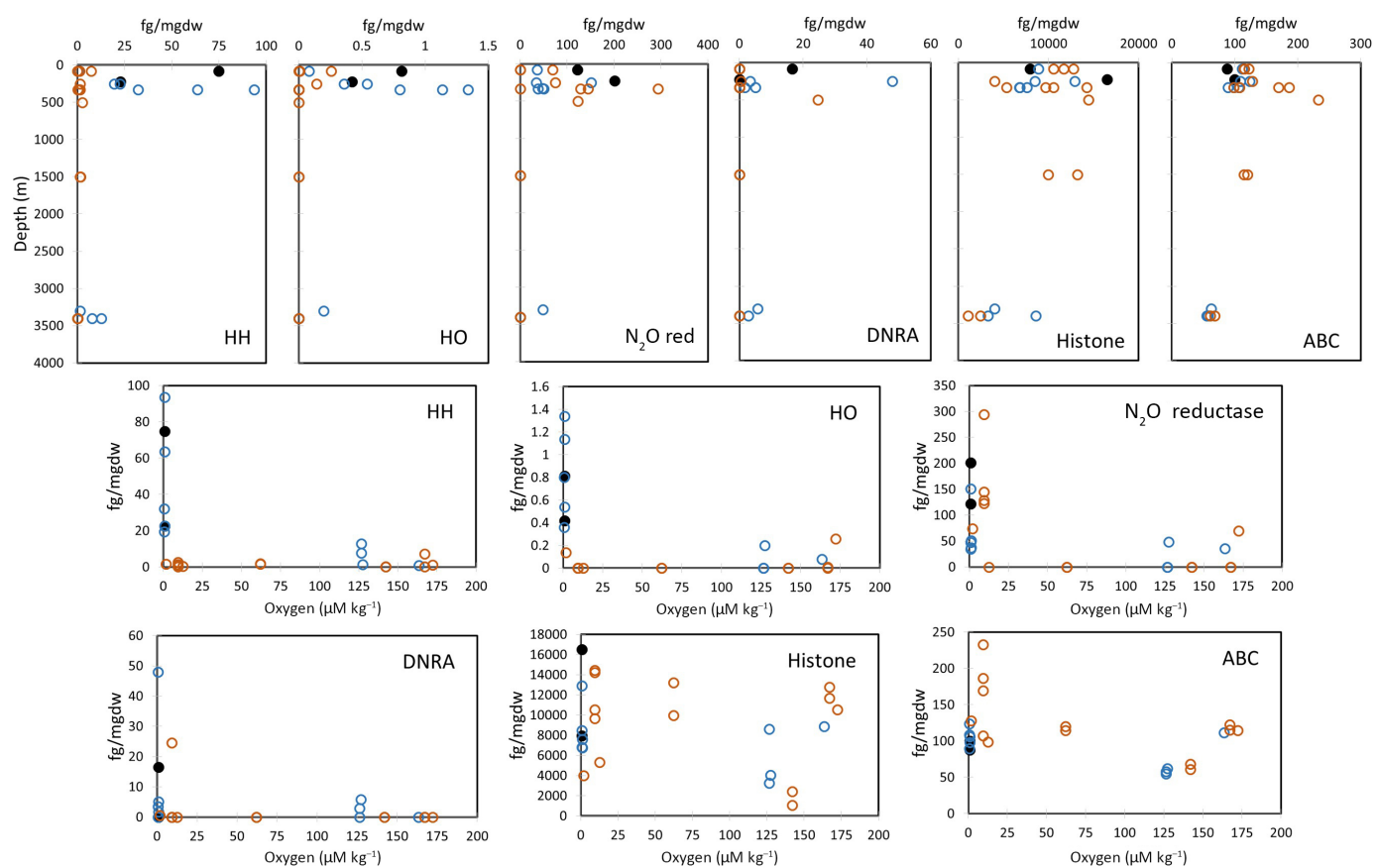

Figure 6. Target peptide quantifications. The upper row shows peptide quantifications as a function of depth, and the lower middle panels as a function of oxygen. $\mathrm{HH}$ combines data from 10 peptides specific to three forms of the anammox-specific enzyme hydrazine hydrolase. HO shows results from four peptides specific to the anammox enzyme hydroxylamine/hydrazine oxidoreductase. Three peptides specific to $\mathrm{N}_{2} \mathrm{O}$ reductase, the enzyme that catalyzes the final step of denitrification, were quantified. DNRA denotes three peptides specific to cytochrome c nitrite reductase (nrfA), a key enzyme in dissimilatory nitrate reduction to ammonium. Histone identifies two peptides specific to the eukaryote-specific $\mathrm{H} 4$ tetramer. $\mathrm{ABC}$ identifies two peptides specific to the general class of $\mathrm{ABC}$ transporter proteins commonly found in active (living) bacteria. (Color scheme for symbols same as in Fig. 3.).

many different components, such as (M1) the possibility that anoxic degradation is sufficiently slower or less comprehensive relative to oxic carbon remineralization (Van Mooy et al., 2002); (M2) chemoautotrophy and a highly efficient microbial loop within the ODZ might add carbon to the flux (Close et al., 2014; Roullier et al., 2014); (M3) zooplankton migration into ODZ regions might enhance chemoautotrophy by providing dissolved nutrients, might result in defecation and "enhanced" fluxes within the upper ODZ (Wishner et al., 2013) or might reduce remineralization if population sizes are small; and (M4) additions of ballast might sorb and protect organic matter from decay (M4a; Arnarson and Keil, 2005; Howard et al., 2006) or change sinking speeds (M4b; Berelson, 2002; Roullier et al., 2014), (M5) inputs of refractory organic matter (Goni et al., 2009), and (M6) temperature effects (Marsay et al., 2015).

Although our data set cannot directly evaluate each of these potential mechanisms, the multiple proxy approach we employed, combined with our shipboard incubation experiments and recent literature by Rouillier et al. (2014), can be used to develop a heuristic model of the particle flux in the Arabian Sea ODZ.

\subsection{M1: carbon remineralization in $\mathrm{ODZ}$ regions is relatively ineffectual}

In sediments there is a well-established "oxygen effect" where organic carbon remineralization is more extensive under oxic rather than reducing conditions, especially over timescales of months to millennia (Arnarson and Keil, 2007; Cowie et al., 1995; Hedges et al., 1999). Little is known, however, about how effective this mechanism is over short time periods or for organic material in the water column. Hartnett et al. (1998) invoked an oxygen effect to explain consistencies between sediments and sinking particles, but others, including Lee (1992), have found little or no direct evidence of such an effect over time periods of days. A particle with a sinking speed between 10 and $300 \mathrm{~m} \mathrm{~d}^{-1}$ (Riley et al., 2012) will spend 1-50 days in a typical ODZ $(\sim 500 \mathrm{~m}$ thick; Deutsch et al., 2011), suggesting that, for this mechanism to be important, it must operate over relatively short time periods. Our data allow evaluation of this hypothesis via incubation experiments conducted at different oxygen concentrations, and by evaluating proxies that might suggest an oxygen effect in samples collected by the net traps.

The deck-board incubation studies (Fig. 7) strongly suggest an oxygen effect, with a threshold of about $20 \mu \mathrm{M}$ under our conditions. In fact, when the oxygen concentration 


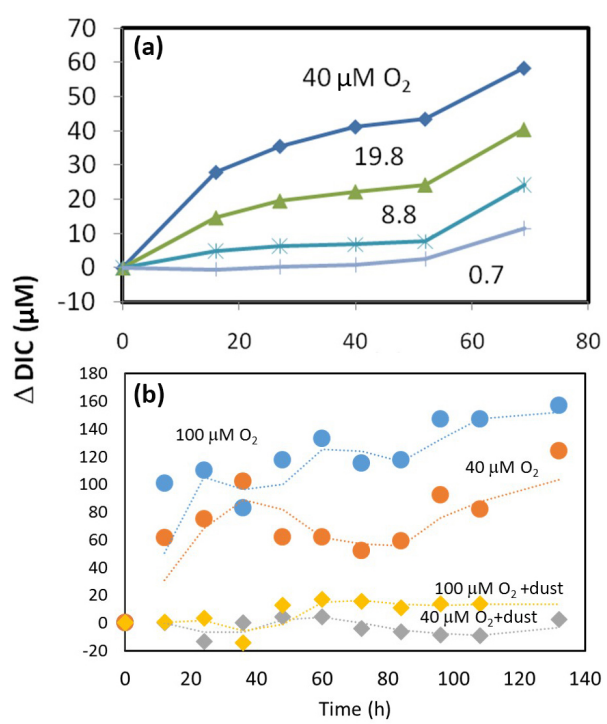

Figure 7. Incubation studies evaluating the change in DIC under different initial oxygen conditions (a) and with or without added dust from the Sahara (b). Sinking particles from station 3, $80 \mathrm{~m}$ depth, were added to incubation bags and alkalinity, $\mathrm{pH}$ and nutrients were measured. DIC calculated assuming that the only changes to the alkalinity were driven by changes in nutrient concentrations (Van Mooy et al., 2002). Dashed lines denote a running average of 2 points.

was below $1 \mu \mathrm{mM}$, there was no observable increase in DIC production for the first $48 \mathrm{~h}$ of incubation. This is consistent with previous work of Ploug et al. (2001, 2008), who suggested that microbial communities on sinking particles would begin switching from aerobic to anaerobic respiratory pathways at approximately these same concentrations. The detection of an "oxygen effect" in the incubations is suggestive, but given that particles and associated microbial communities were concentrated and subjected to abrupt changes in oxygen tension prior to beginning the experiments, these types of incubation studies need to be taken with a grain of salt. If the results are to be generalized to the sinking particles under more native conditions, either experiments need to be conducted under more realistic conditions or geochemical measurements that allow evaluation of an oxygen effect need to be evaluated on the sinking particles themselves.

Two amino acid indicators are commonly used in sediments to evaluate degradation: the mole percentage of nonprotein amino acids (higher being more degraded) and the Dauwe-Middelburg index (Dauwe et al., 1999) (lower being more degraded). When measured on the sinking particles, both of these indicators suggest a difference between the ODZ stations and the more oxygenated station 3, with the sinking particles at station 3 having undergone more extensive degradation (Fig. 5).

Another possible hint to an oxygen effect is the attenuation of the histone protein marker in the samples. Histones are in- soluble alkaline proteins that package DNA into structural units (nucleosomes) (Kornberg, 1974). Histones are found only in eukaryote nuclei, not in bacteria or archaea (Kornberg, 1974). We targeted the general diatom histone H4 because it is a good tracer for the transfer of diatom protein to the ocean interior (Bridoux et al., 2015). If there is an oxygen effect, we would expect histones traveling through the ODZ to be less effectively degraded relative to the oxic station 3 , but we do not observe this. Instead, our histone values show no discerning trends with depth or oxygen content, suggesting that there is no clear oxygen effect for these proteins. Thus, the targeted peptidomics data are inconsistent with the overall total amino acid data, suggesting that histones do not degrade in the same way the bulk amino acid pool does. How these different measures relate and whether one is a better marker for a degradative effect remain unknown.

Finally, measuring the amount of carbon on mineral surfaces relative to the total organic carbon content of a sample can be a useful tool for evaluating the relative "degradative state" of organic matter in sediments (Arnarson and Keil 2001, 2007). Fresh particles are typically rich in organic matter (low $\mathrm{C}_{\text {surf }}: \mathrm{C}_{\text {bulk }}$ ), whereas particles that have undergone degradation usually have their remaining carbon associated with mineral surfaces (high $\mathrm{C}_{\text {surf }}$ : $\mathrm{C}_{\text {bulk }}$ ). Extending this concept to the sinking particles, if an oxygen effect is the dominant reason for enhance fluxes, we might expect the ODZ particles to have lower $\mathrm{C}_{\text {surf }}: \mathrm{C}_{\text {bulk }}$ ratios relative to the more oxic samples (Fig. 4e). Indeed, we observe that $C_{\text {surf }}$ : $C_{\text {bulk }}$ values at station 3 are higher than for the two ODZ stations.

Thus, the majority of indicators we measured are at least partially consistent with an oxygen effect, but the evidence to date is somewhat circumstantial and certainly not definitive. It is known that addition of fresh organic matter to incubations stimulates denitrification (Babbin et al., 2014; Chang et al., 2014), suggesting that denitrification is responsive to additions of carbon, but what is not known is whether in situ denitrification rates would match those of aerobic respiration under similar conditions.

\subsection{M2: community growth efficiency and chemoautotrophy}

Because ODZ regions host a wide range of chemoautotrophic organisms, there is the possibility that chemoautotrophy adds carbon to the sinking flux (Close et al., 2014). This has been termed "substrate injection", and if this is common in the Arabian Sea ODZ, there should be bulk isotopic and biomarker measurements supporting this added material. Of the things we measured, the bulk stable ${ }^{13} \mathrm{C}$ isotopic composition of the sinking material might be the best indicator of chemoautotrophy. Lipids from ODZ chemoautotrophic organisms can be isotopically enriched (Close et al., 2014), suggesting that the bulk material, if it contains significant chemoautotrophically derived carbon, might be similarly enriched. Our data (Fig. 3) show enrichment of the ${ }^{13} \mathrm{C}$ of the 
bulk sinking material at station 2 relative to station 3 . This indicates that the sinking particles may contain a significant chemoautotrophic input. Because the end-member isotopic values are not known, a mixing model of euphotic zone and ODZ sources cannot be made. Nonetheless, the observation that the ODZ compositions are all enriched relative to the samples from Station 3 suggests measurable inputs of material produced within the ODZ.

What material might this be? Quantifications of peptides associated with the chemoautotrophic process anammox suggest that anammox proteins are present but do not contribute substantially to the sinking flux (Fig. 6). The two anammox peptide biomarkers were rarely detected $(<50 \%$ of the samples contained measurable amounts of the markers) and their abundance per unit mass was only $1-20 \%$ of that $\mathrm{N}_{2} \mathrm{O}$ reductase, the peptide marker for the heterotrophic denitrification. We interpret this as evidence that heterotrophic proteins responsible for denitrification dominate in particles over chemoautotrophic processes that also result in the formation of nitrogen gas. This is consistent with the work of Fuchsman et al. (2011, 2012), who suggested that anammox is primarily a water column process (free-living bacteria), and also consistent with other work conducted during our cruise suggesting a dominance of denitrification over anammox at the time of our sampling (Ward et al., 2009).

How do we reconcile two biomarkers that appear to advocate opposite interpretations? The observations are not necessarily at odds. As early as 1994, Azam et al. (1994) proposed a complex microbial loop within the Arabian Sea ODZ comprising of active free-living and particle-attached bacteria working together to effectively transfer material between the dissolved, suspended and sinking pools. Close et al. (2014) suggested a something similar based on their lipid data, and Roullier et al. (2014) suggested that the attenuated flux in the Arabian Sea was partly the result of an efficient microbial loop that effectively reconstituted and utilized the energy of the sinking flux. This is a compelling hypothesis that requires further research. What are the growth efficiencies of heterotrophic communities in oxygenated waters relative to those of the heterotrophic-autotrophic community in an ODZ? If the ODZ community grows with less respiratory loss, this might account for the appearance of chemoautotrophic carbon in the sinking particles and might also be the mechanism leading to the "enhanced flux".

It is worth noting that the (M1) oxygen effect and (M2) efficiencies and chemoautotrophy mechanisms are not easily dissected and discerned from each other. For example, since the shipboard incubations measured the accumulation of DIC, a change in the growth efficiency of the microbial community as a function of oxygen content would result in the same observation (less DIC accumulation) as a true oxygen effect would. Similarly, since we did not develop a peptide marker for aerobic respiration, we cannot compare the abundance of the denitrification peptide marker against an oxic counterpart. Thus, we cannot say whether there is rela- tively less protein associated with denitrification in the ODZ relative to aerobic respiratory proteins in the oxygenated waters.

Our bacterial $\mathrm{ABC}$ transporter protein data provide clues pertinent to this issue. ABC transporter proteins are ATPrequiring enzymes used to transport compounds across membranes. They are among the most commonly detected proteins in the ocean (Tanoue et al., 1995; Wang et al., 2011) and are critical for the heterotrophic function of acquiring organic compounds from the environment. Thus, they are a good marker for heterotrophic processing. The ATP transporter peptide we evaluated was quite abundant at all stations $\left(150-250 \mathrm{fg} \mathrm{mgdw}^{-1}\right)$, but in general there was more of this peptide at the oxic station 3 relative to the two stations within the ODZ (Fig. 6). This is suggestive that oxic station 3 might have more active heterotrophic communities on the particles than at the ODZ sites (though concentrations do not equate directly to rates). Thus, the $\mathrm{ABC}$ transporter protein data are consistent with more heterotrophy at station 3, but they do not preclude an efficient microbial loop at the ODZ stations, where energy transfer can be achieved using solutes such as nitrite and ammonium (e.g., the anammox process) that do not require $\mathrm{ABC}$ transporters. Thus, both the (M1) oxygen effect and (M2) chemoautotrophy mechanisms are viable given our data.

\subsection{M3: zooplankton}

One of the more intriguing mechanisms that might influence the flux is the presence and activity of zooplankton. Their actions may alter the flux in a variety of ways. If they feed in surface waters and then migrate into the ODZ for protection from fish, and they defecate in the ODZ, this would result in deliver of packaged particles that sink without having to pass the upper portions of the ODZ where remineralization is fastest (Cavan et al., 2015; Wishner et al., 2013). An argument against this is that if it occurs within the ODZ it should also occur within oxic water columns (e.g., Cavan et al., 2015). Alternatively, if zooplankton feed and defecate in surface waters and are inactive in the ODZ, then sinking particles would simply pass them by and not be re-ingested or repacked.

In addition to providing fecal material, zooplankton deliver dissolved materials (ammonium) that can promote chemoautotrophy (anammox), thus indirectly leading to "enhanced" fluxes. Our data set is very limited in its ability to address the role of zooplankton. Even though many sediment traps were deployed, our vertical resolution is too low to evaluate whether there is a "spike" in the flux at the depth that the zooplankton migrate to. We also have no zooplanktonspecific biomarker to help evaluate whether their fecal material is a more important component of the sinking flux within the ODZ.

In a recent study, Roullier et al. (2014) used an underwater vision profiler (UVP) to collect high-resolution data 
of the particle flux within the Arabian Sea ODZ. They observed increases in the sinking flux that were associated with zooplankton assemblages living at the deeper boundaries of the ODZ, and suggest that zooplankton-derived injections of sinking particles are an important component controlling the deep flux. These data were collected deeper than our sediment traps and, thus, while their data clearly support a zooplankton contribution to the issue, they do not help explain why we (and others) observe attenuated fluxes above the zone where the zooplankton aggregated, within the heart of the ODZ.

\subsection{M4: ballast effects of mineral protection and sinking speed}

Similar to an oxygen effect, there is abundant evidence that mineral protection is an important mechanism promoting organic matter survival and burial in long-term sediment records (M4a) (Keil and Mayer, 2014; Kennedy and Wagner, 2011; Mayer, 1994). A variety of experimental approaches have also shown mineral protection occurs for some fresh material sorbed to mineral surfaces (for example; Arnarson and Keil, 2005; Le Moigne et al., 2013). In the water column, a mineral protection mechanism would rely on either biominerals created by plankton or the delivery of lithogenic minerals from land. Aeolian dusts from Africa deliver minerals (and pollutants; Dachs et al., 1999) to the Arabian Sea, where they are thought to sensitively influence the dynamics of sinking particles (Barkmann et al., 2010). We evaluated the potential effects of dust inputs by adding dust to shipboard incubations at a variety of oxygen contents (Fig. 7) and observed immediate reduction in DIC accumulation rates. This suggests that aeolian sources of mineral to the Arabian Sea ODZ may directly influence the rate at which organic matter is remineralized, thus enhancing the flux. Our experiments were conducted by adding large quantities of dust $(\sim 4$ times greater) relative to the maximal seasonal input (Barkmann et al., 2010), suggesting that we may have observed the maximal effect.

To seek corroboration between the incubations and the sediment trap samples, we analyzed the sediment trap material by XPS. Interestingly, no aluminum was detected in any sample, suggesting that terrestrial inputs of lithogenic material were minimal during the time of our sampling. Silica and calcium were both detected at $5-10 \mathrm{wt} \%$ of the surface material. The only differences observed for the biogenic markers was that the calcium content at station 2 (ODZ) was lower than at stations 1 or 3 . This suggests that the sinking particles at station 2 were slightly richer in Si-rich diatom material relative carbonate compared to the other two stations.

Overall, our data are inconclusive about the effect of mineral on the remineralization rate of the organic matter; incubations suggest a strong effect, but direct measurements of the sinking particles suggest relatively minor contributions of biogenic mineral and no detectable aeolian dust. These results do not exclude this as an important mechanism, and other modeling and data analysis efforts have suggested that it must be important in the Arabian Sea (Armstrong et al., 2002; Barkmann et al., 2010; Howard et al., 2006; Klaas and Archer, 2002). It may simply be that our sampling period (transition to the intermonsoon) was the incorrect period to observe a strong effect.

Mineral inputs can potentially control more than just the reactivity of whatever organic material is sorbed to it, the abundance of mineral in the sinking particles plays a large role controlling the sinking speed (M4b) (Burd et al., 2010; Jackson and Burd, 2002). Given a single and constant degradation rate, any change in sinking speed will change how long the particle spends in the ODZ and thus influence how much it is remineralized there. Complicating matters is the fact that the ocean contains many different types of particles that aggregate and disaggregate and sink at different speeds. Riley et al. (2012) has suggested that fast sinking particles can typically account for the carbon demand of the deep sea, and that more slowly sinking particles are effectually remineralized within the water column. Use of the Martin attenuation coefficient does not help in this regard because it combined the two terms, but the ballast model allows some insight (Armstrong et al., 2002; Klaas and Archer, 2002; Le Moigne et al., 2012). If ballasting is an important control on sinking speed, and sinking speed controls the flux attenuation in the ODZ, then samples from the ODZ should have proportionally more minerals compared to station 3 . Our data show the opposite trend; samples from station 3 (more oxygenated) have higher percentages of inorganic material (Fig. 3). This is inconsistent with ballast-driven sinking speeds being the primary driver of the reduced attenuation in the ODZ. However, as with everything else we measured, the data have the caveat that we did not measure sinking speeds directly, nor did we separate the material into pools with different sinking rates. In other studies where that has been done, the deep flux has been attributed to ballasted organic matter with fast sinking speeds or to fast-sinking materials derived from zooplankton (Cavan et al., 2015).

Conversely, organic material has the potential to minimize any sinking speed effect of mineral ballast (Azetsu-Scott and Passow, 2004). As particles sink they interact with other components in the water such as exopolymers, and if these materials become associated, sinking speeds can slow and even become negative (buoyant). Thus, the impact of ballast on organic matter reactivity and sinking speed remains an area ripe for further research. To summarize, direct evidence of a ballasting effect on the collected sinking particles is inconclusive, but lab studies with added lithogenic material show an inhibition in degradation rates, suggesting that further research on this topic is warranted. 


\subsection{M5: addition of recalcitrant organic material}

One poorly evaluated possibility is that ODZ regions, for whatever reason, are prone to having refractory material within them, thus providing sinking particles with material that is naturally resistant to degradation. We assessed this by measuring terrestrial lignin phenols in the trap material. Our assumption was that the lignin would be highly refractory and that if this mechanism was important we would detect more lignin at the ODZ stations relative to station 3 further south. This is somewhat logical, as (a) the lignin found in the open in the ocean is generally thought to be refractory (Goni et al., 2009; Meyersschulte and Hedges, 1986), (b) station 1 is closest to the Indus River - a known and important source of lignin to the Arabian Sea (Cowie, 2005; Cowie et al., 1999; Vandewiele et al., 2009), and (c) station 2 is in a region where the dust deposition is roughly $2-3$ times that of station 3 (Grand et al., 2015). However, the lignin yield was quite low, comparable to that found in the dissolved pool of the equatorial Pacific (Meyersschulte and Hedges, 1986) and we did not observe any differences in the quantities or compositions of the minimal lignin contribution to the sinking particles at the three stations and the contribution of lignin to the total organic matter was far less than $0.1 \%$, implying that refractory organic material from land was not an important component controlling the flux.

An additional component that we did not evaluate is the possibility that the phytoplankton community above the ODZ waters natively create "selectively preserved" organic matter that is strongly resistant to remineralization such as algeanans (Gelin et al., 1996, 1999). However, visualizations of the sinking material using a dissecting scope aboard ship did not result in any suggestion of differences between the various stations in the physical structure or composition of the sinking material.

\subsection{M6: changes in temperature}

Matsumoto (2007) suggested that colder oceans more effectively transfer carbon to the interior because degradation is temperature-dependent and Marsay et al. (2015) showed evidence of this in the North Atlantic. Could temperature impact fluxes through an ODZ? At first glance, it seems unlikely given that the three major ODZ regions of the ocean are in tropical waters and thus should have higher attenuation rates. The median temperature of the upper $500 \mathrm{~m}$ in the Arabian Sea during our sampling was uniform at $18.5^{\circ} \mathrm{C}$ and there was no difference between stations. Comparing our flux attenuation terms to those in Marsay et al. (2015) for approximately the same temperature (see their Fig.2), we observe that our attenuation coefficients of $0.59,0.63$ and 0.98 are all much lower than the "expected" value of $\sim 1.2$. This implies that the temperature effect on sinking flux attenuation is not the explanation for our Arabian Sea data.

\subsection{A heuristic model for organic matter cycling in an ODZ}

No single parameter we measured or mechanism explored seems to singularly control the flux through the Arabian Sea ODZ, but the mechanisms (M1) oxygen effect and (M2) growth efficiency and chemoautotrophy have the strongest support within our data set and based on the literature. The effect of (M3) zooplankton and of mineral ballast (which occurs as part of several mechanisms) appears to be most important deeper within the ODZ (deeper than our sediment traps were deployed; Roullier et al., 2014), and the role of (M4b) sinking speed remains unclear. The role of (M4a) mineral protection seems plausible and is supported by model efforts (Barkmann et al., 2010; Howard et al., 2006) but since no lithogenic minerals were detected by XPS in our samples, mineral protection remains to be further evaluated and might likely only be important under certain circumstances. The only mechanisms that we can rule out appears to be that of (M5) refractory terrestrial inputs and (M6) temperature, but we note that we did not evaluate algeanans.

A conceptual model for how an ODZ system might funnel carbon to the deep sea thus starts with the upper ODZ being a region of intense microbial activity where respiratory reactions are either slowed by the lack of oxygen (M1, oxygen effect) or are highly efficient at retaining energy within the system (high growth efficiency, M2). Disentangling these two possibilities is of importance if we are to better understand the forces controlling carbon fluxes in a changing ocean, and also important for understanding the role of the changing oxygen content of the oceans (Stramma et al., 2010). Bacterial growth efficiencies are known to vary widely from $<5$ to $\sim 60 \%$ (del Giorgio and Cole, 1998) and this is thought to be controlled by a combination of factors including source materials and maintenance energy costs. To our knowledge, these things have not been evaluated in ODZ regions and comparisons between oxic waters and ODZs have thus not been made. As a thought exercise, assuming an aerobic growth efficiency of $10 \%$, to halve the attenuation and double export out of a hypothetical ODZ with similar inputs, the microbial efficiency of the bacterial community in the ODZ need only double to $20 \%$. Similarly, the oxygen effect need not be large; a halving of the degradation rate would result in a doubling of the flux. Both these terms (growth efficiency and remineralization rate) are very poorly explored for ODZ systems.

Assuming a higher growth efficiency relative to oxic waters, the ODZ microbial community could then funnel energy to its chemoautotrophic community. The major chemoautotrophs in ODZ regions are thought to be slow-growing anammox bacteria (Lam and Kuypers, 2011); although these might grow slowly, they also keep biomass within the ODZ until they are grazed or otherwise transferred into the sinking pool. This combination of reduced respiration, increased efficiency and chemoautotrophy probably explains most obser- 
vations of upper ODZ regions, including the presence of relatively high amounts of non-sinking loosely aggregated material (Roullier et al., 2014). The factors controlling how this material is transferred (or not) to the sinking pool remain to be explored. The inputs of dust are likely to enhance the flux by sorbing and protecting dissolved organic matter (Burdige, 2007) and could also change sinking speeds by providing ballast, but again, this remains to be directly demonstrated.

Deeper within the ODZ, two processes appear likely to be important; the presence of a deep zooplankton population (Roullier et al., 2014; Wishner et al., 2008) likely repackages suspended material and adds to the sinking flux, and the remineralization of slowly sinking organic matter results in sinking rates that increase as a function of depth (Berelson, 2002). The overall observation of "enhanced" fluxes is thus the result of a complex series of processes, each of which may dominate at any given time or depth.

To evaluate this conceptual model, and to begin to place values on each of the potential mechanisms, it is necessary to change our approach to evaluating sinking particles in ODZ regions. Particles need to be sampled and/or evaluated with higher vertical resolution than is currently done using sediment traps (e.g., Roullier et al., 2014), and new and existing methods for evaluating sinking speeds and particle dynamics (McDonnell et al., 2015) need to be applied to ODZ regions. The sinking, suspended and free-living/dissolved components of the carbon and microbial community should be evaluated together, and additional biomarkers for evaluating different sources and reactions need to be developed and applied. Examinations of zooplankton dynamics must to be incorporated into these microbial and geochemical studies of carbon flow. Finally, it would be useful to simultaneously evaluate both the remineralization rates and the sinking speeds of different types of particles in order to better understand how each factor influences carbon export.

\section{The Supplement related to this article is available online at doi:10.5194/bg-13-2077-2016-supplement.}

Author contributions. Richard G. Keil and Allan H. Devol managed the project and Richard G. Keil wrote the manuscript with the assistance of Allan H. Devol. Jacquelyn A. Neibauer oversaw all laboratory analyses, processed samples on all the mass spectrometers, and helped with manuscript writing and proof reading. Christina Biladeau measured the amino acids and conducted the mineral SA and XPS analyses as part of her under-graduate degree in oceanography and interpreted early data sets as a part of her educational experience. Kelsey van der Elst collected the sediment trap samples, helped with incubation experiments and made substantial improvements to the sampling plan while at sea.
Acknowledgements. This research was funded by US-NSF grants 0926395 and 1153935 to R. G. Keil. We thank Heidi Berkenbosch and Chloe Anderson for help at sea and in the lab, and the captain and crew of the R/V Roger Revelle for their help collecting samples and deploying instrumentation. Thanks to Colleen Kellogg and Maxime Bridoux for development and implementation of the isotope pairing amino acid technique. Thanks from R. G. Keil to Andy Shouse and Phil Bell for encouraging me to be aware of my scientific blind spots and not to rely on oxygen effects as an overall solution to everything. The two anonymous referees and the associate editor greatly helped improve the manuscript.

Edited by: C. Rabouille

\section{References}

Armstrong, R. A., Lee, C., Hedges, J. I., Honjo, S., and Wakeham, S. G.: A new, mechanistic model for organic carbon fluxes in the ocean based on the quantitative association of POC with ballast minerals, Deep-Sea Res. Pt. II, 49, 219-236, 2002.

Arnarson, T. S. and Keil, R. G.: Organic-mineral interactions in marine sediments studied using density fractionation and $\mathrm{X}$-ray photoelectron spectroscopy, Org. Geochem., 32, 1401-1415, 2001.

Arnarson, T. S. and Keil, R. G.: Influence of organic-mineral aggregates on microbial degradation of the dinoflagellate Scrippsiella trochoidea, Geochim. Cosmochim. Ac., 69, 2111-2117, 2005.

Arnarson, T. S. and Keil, R. G.: Changes in organic matter-mineral interactions for marine sediments with varying oxygen exposure times, Geochim. Cosmochim. Ac., 71, 3545-3556, 2007.

Azam, F., Steward, G. F., Smith, D. C., and Ducklow, H. W.: Significance of bacteria in carbon fluxes in the Arabian Sea, P. Indian A. S.-Earth, 103, 341-351, 1994.

Azetsu-Scott, K. and Passow, U.: Ascending marine particles: significance of transparent exopolymer particles (TEP) in the upper ocean, Limnol. Oceanogr., 49, 741-748, 2004.

Babbin, A. R., Keil, R. G., Devol, A. H., and Ward, B. B.: Organic Matter Stoichiometry, Flux, and Oxygen Control Nitrogen Loss in the Ocean, Science, 344, 406-408, 2014.

Barkmann, W., Schafer-Neth, C., and Balzer, W.: Modelling aggregate formation and sedimentation of organic and mineral particles, J. Marine Syst., 82, 81-95, 2010.

Berelson, W. M.: Particle settling rates increase with depth in the ocean, Deep-Sea Res. Pt. II, 49, 237-251, 2002.

Bertrand, E. M., Moran, D. M., McIlvin, M. R., Hoffman, J. M., Allen, A. E., and Saito, M. A.: Methionine synthase interreplacement in diatom cultures and communities: Implications for the persistence of B-12 use by eukaryotic phytoplankton, Limnol. Oceanogr., 58, 1431-1450, 2013.

Bopp, L., Resplandy, L., Orr, J. C., Doney, S. C., Dunne, J. P., Gehlen, M., Halloran, P., Heinze, C., Ilyina, T., Séférian, R., Tjiputra, J., and Vichi, M.: Multiple stressors of ocean ecosystems in the 21st century: projections with CMIP5 models, Biogeosciences, 10, 6225-6245, doi:10.5194/bg-10-6225-2013, 2013.

Bridoux, M. C., Neibauer, J., Ingalls, A. E., Nunn, B. L., and Keil, R. G.: Suspended marine particulate proteins in coastal and oligotrophic waters, J. Marine Syst., 143, 39-48, 2015. 
Buesseler, K. O. and Boyd, P. W.: Shedding light on processes that control particle export and flux attenuation in the twilight zone of the open ocean, Limnol. Oceanogr., 54, 1210-1232, 2009.

Bulow, S. E., Rich, J. J., Naik, H. S., Pratihary, A. K., and Ward, B. B.: Denitrification exceeds anammox as a nitrogen loss pathway in the Arabian Sea oxygen minimum zone, Deep-Sea Res. Pt. I, 57, 384-393, 2010.

Burd, A. B., Hansell, D. A., Steinberg, D. K., Anderson, T. R., Aristegui, J., Baltar, F., Beaupre, S. R., Buesseler, K. O., DeHairs, F., Jackson, G. A., Kadko, D. C., Koppelmann, R., Lampitt, R. S., Nagata, T., Reinthaler, T., Robinson, C., Robison, B. H., Tamburini, C., and Tanaka, T.: Assessing the apparent imbalance between geochemical and biochemical indicators of meso- and bathypelagic biological activity: What the @\$\#! is wrong with present calculations of carbon budgets?, Deep-Sea Res. Pt. II, 57, 1557-1571, 2010.

Burdige, D. J.: Preservation of organic matter in marine sediments: Controls, mechanisms, and an imbalance in sediment organic carbon budgets?, Chem. Rev., 107, 467-485, 2007.

Burdige, D. J.: Preservation of organic matter in marine sediments: Controls, mechanisms, and an imbalance in sediment organic carbon budgets?, Chem. Rev., 107, 467-485, 2007.

Cavan, E. L., Le Moigne, F. A. C., Poulton, A. J., Tarling, G. A., Ward, P., Daniels, C. J., Fragoso, G. M., and Sanders, R. J.: Attenuation of particulate organic carbon flux in the Scotia Sea, Southern Ocean, is controlled by zooplankton fecal pellets, Geophys. Res. Lett., 42, 821-830, 2015.

Chang, B. X., Rich, J. R., Jayakumar, A., Naik, H., Pratihary, A. K., Keil, R. G., Ward, B. B., and Devol, A. H.: The effect of organic carbon on fixed nitrogen loss in the eastern tropical South Pacific and Arabian Sea oxygen deficient zones, Limnol. Oceanogr., 59, 1267-1274, 2014.

Close, H. G., Wakeham, S. G., and Pearson, A.: Lipid and ${ }^{13} \mathrm{C}$ signatures of submicron and suspended particulate organic matter in the Eastern Tropical North Pacific: Implications for the contribution of Bacteria, Deep-Sea Res. Pt. I, 85, 15-34, 2014.

Cowie, G.: The biogeochemistry of Arabian Sea surficial sediments: A review of recent studies, Prog. Oceanogr., 65, 260-289, 2005.

Cowie, G. L. and Hedges, J. I.: Improved amino acid quantification in environmental samples - charge matched recovery standards and reduced analysis time, Mar. Chem., 37, 223-238, 1992a.

Cowie, G. L. and Hedges, J. I.: The role of anoxia in organic matter preservation in coastal sediments - relative stabilities of the major biochemicals under oxic and anoxic depositional conditions, Org. Geochem., 19, 229-234, 1992b.

Cowie, G. L. and Hedges, J. I.: Biochemical indicators of diagenetic alteration in natural organic matter mixtures, Nature, 369, 304 307, 1994

Cowie, G. L., Hedges, J. I., Prahl, F. G., and Delange, G. J.: Elemental and major biochemical changes acros an oxidation front in a relict turbidite - an oxygen effect, Geochim. Cosmochim. Ac., 59, 33-46, 1995.

Cowie, G. L., Calvert, S. E., Pedersen, T. F., Schulz, H., and von Rad, U.: Organic content and preservational controls in surficial shelf and slope sediments from the Arabian Sea (Pakistan margin), Mar. Geol., 161, 23-38, 1999.

Dachs, J., Bayona, J. M., Ittekkot, V., and Albaiges, J.: Monsoondriven vertical fluxes of organic pollutants in the western Arabian Sea, Environ. Sci. Technol., 33, 3949-3956, 1999.
Dale, A. W., Sommer, S., Lomnitz, U., Montes, I., Treude, T., Liebetrau, V., Gier, J., Hensen, C., Dengler, M., Stolpovsky, K., Bryant, L. D., and Wallmann, K.: Organic carbon production, mineralisation and preservation on the Peruvian margin, Biogeosciences, 12, 1537-1559, doi:10.5194/bg-12-1537-2015, 2015.

Dalsgaard, T., Canfield, D. E., Petersen, J., Thamdrup, B., and Acuna-Gonzalez, J.: $\mathrm{N}_{2}$ production by the anammox reaction in the anoxic water column of Golfo Dulce, Costa Rica, Nature, 422, 606-608, 2003.

Dauwe, B., Middelburg, J. J., Herman, P. M. J., and Heip, C. H. R.: Linking diagenetic alteration of amino acids and bulk organic matter reactivity, Limnol. Oceanogr., 44, 1809-1814, 1999.

del Giorgio, P. A. and Cole, J. J.: Bacterial growth efficiency in natural aquatic systems, Annu. Rev. Ecol. Syst., 29, 503-541, 1998.

Deutsch, C., Brix, H., Ito, T., Frenzel, H., and Thompson, L.: Climate-Forced Variability of Ocean Hypoxia, Science, 333, 336-339, 2011.

Devol, A. H. and Hartnett, H. E.: Role of the oxygen-deficient zone in transfer of organic carbon to the deep ocean, Limnol Oceanogr., 46, 1684-1690, 2001.

DeVries, T., Deutsch, C., Primeau, F., Chang, B., and Devol, A.: Global rates of water-column denitrification derived from nitrogen gas measurements, Nat. Geosci., 5, 547-550, 2012.

Fuchsman, C. A., Kirkpatrick, J. B., Brazelton, W. J., Murray, J. W., and Staley, J. T.: Metabolic strategies of free-living and aggregate-associated bacterial communities inferred from biologic and chemical profiles in the Black Sea suboxic zone, Fems Microbiol. Ecol., 78, 586-603, 2011.

Fuchsman, C. A., Staley, J. T., Oakley, B. B., Kirkpatrick, J. B., and Murray, J. W.: Free-living and aggregate-associated Planctomycetes in the Black Sea, Fems Microbiol. Ecol., 80, 402-416, 2012.

Gelin, F., Boogers, I., Noordeloos, A. A. M., Damste, J. S. S., Hatcher, P. G., and deLeeuw, J. W.: Novel, resistant microalgal polyethers: An important sink of organic carbon in the marine environment?, Geochim. Cosmochim. Ac., 60, 1275-1280, 1996.

Gelin, F., Volkman, J. K., Largeau, C., Derenne, S., Damste, J. S. S., and De Leeuw, J. W.: Distribution of aliphatic, nonhydrolyzable biopolymers in marine microalgae, Org. Geochem., 30, 147-159, 1999.

Goni, M. A. and Montgomery, S.: Alkaline $\mathrm{CuO}$ oxidation with a microwave digestion system: Lignin analyses of geochemical samples, Anal. Chem., 72, 3116-3121, 2000.

Goni, M. A., Aceves, H., Benitez-Nelson, B., Tappa, E., Thunell, R., Black, D. E., Muller-Karger, F., Astor, Y., and Varela, R.: Oceanographic and climatologic controls on the compositions and fluxes of biogenic materials in the water column and sediments of the Cariaco Basin over the Late Holocene, Deep-Sea Res. Pt. I, 56, 614-640, 2009.

Grand, M. M., Measures, C. I., Hatta, M., Hiscock, W. T., Buck, C. S., and Landing, W. M.: Dust deposition in the eastern Indian Ocean: The ocean perspective from Antarctica to the Bay of Bengal, Global Biogeochem. Cy., 29, 357-374, 2015.

Haake, B., Ittekkot, V., Ramaswamy, V., Nair, R. R., and Honjo, S.: Fluxes of amino acids and hexosamines to the deep Arabian Sea, Mar. Chem., 40, 291-314, 1992. 
Hartnett, H. E., Keil, R. G., Hedges, J. I., and Devol, A. H.: Influence of oxygen exposure time on organic carbon preservation in continental margin sediments, Nature, 391, 572-574, 1998.

Hartnett, H. E. and Devol, A. H.: Role of a strong oxygen-deficient zone in the preservation and degradation of organic matter: A carbon budget for the continental margins of northwest Mexico and Washington State, Geochim. Cosmochim. Ac., 67, 247-264, 2003.

Hebbeln, D., Marchant, M., and Wefer, G.: Seasonal variations of the particle flux in the Peru-Chile current at $30^{\circ} \mathrm{S}$ under "normal" and El Niño conditions, Deep-Sea Res. Pt. II, 47, 21012128, 2000.

Hedges, J. I. and Keil, R. G.: Sedimentary organic matter preservation: an assessment and speculative synthesis, Mar. Chem., 49, 81-115, 1995.

Hedges, J. I., Clark, W. A., and Cowie, G. L.: Fluxes and reactivities of organic matter in a coastal marine bay, Limnol. Oceanogr., 33, 1137-1152, 1988.

Hedges, J. I., Hu, F. S., Devol, A. H., Hartnett, H. E., Tsamakis, E., and Keil, R. G.: Sedimentary organic matter preservation: A test for selective degradation under oxic conditions, Am. J. Sci., 299, 529-555, 1999.

Hedges, J. I., Baldock, J. A., Gelinas, Y., Lee, C., Peterson, M. L., and Wakeham, S. G.: The biochemical and elemental compositions of marine plankton: A NMR perspective, Mar. Chem., 78, 47-63, 2002.

Howard, M. T., Winguth, A. M. E., Klaas, C., and Maier-Reimer, E.: Sensitivity of ocean carbon tracer distributions to particulate organic flux parameterizations, Global Biogeochem. Cy., 20, 384 393, doi:10.1029/2005GB002499, 2006.

Jackson, G. A. and Burd, A. B.: A model for the distribution of particle flux in the mid-water column controlled by subsurface biotic interactions, Deep-Sea Res. Pt. II, 49, 193-217, 2002.

Jensen, M. M., Lam, P., Revsbech, N. P., Nagel, B., Gaye, B., Jetten, M. S. M., and Kuypers, M. M. M.: Intensive nitrogen loss over the Omani Shelf due to anammox coupled with dissimilatory nitrite reduction to ammonium, Isme J., 5, 1660-1670, 2011.

Keil, R. G. and Cowie, G. L.: Organic matter preservation through the oxygen-deficient zone of the NE Arabian Sea as discerned by organic carbon : mineral surface area ratios, Mar. Geol., 161, 13-22, 1999.

Keil, R. G. and Mayer, L. M.: 12.12 - Mineral Matrices and Organic Matter, in: Turekian HDHK (ed) Treatise on Geochemistry, Second Edn., Elsevier, Oxford, 337-359, 2014.

Keil, R. G., Dickens, A. F., Arnarson, T., Nunn, B. L., and Devol, A. H.: What is the oxygen exposure time of laterally transported organic matter along the Washington margin?, Mar. Chem., 92, 157-165, 2004

Keil, R., Salemme, K., Forrest, B., Neibauer, J., and Logsdon, M.: Differential presence of anthropogenic compounds dissolved in the marine waters of Puget Sound, WA and Barkley Sound, BC, Mar. Pollut. Bull., 62, 2404-2411, 2011.

Kennedy, M. J. and Wagner, T.: Clay mineral continental amplifier for marine carbon sequestration in a greenhouse ocean, P. Natl. Acad. Sci. USA, 108, 9776-9781, 2011.

Kennedy, P., Kennedy, H., and Papadimitriou, S.: The effect of acidification on the determination of organic carbon, total nitrogen and their stable isotopic composition in algae and marine sediment, Rapid Commun. Mass Sp., 19, 1063-1068, 2005.
Klaas, C. and Archer, D. E.: Association of sinking organic matter with various types of mineral ballast in the deep sea: Implications for the rain ratio, Global Biogeochem. Cy., 16, 63-77, doi:10.1029/2001GB001765, 2002.

Kornberg, R. D.: Chromatin structure - repeating unit of histones and DNA, Science, 184, 868-871, 1974.

Kuypers, M. M. M., Sliekers, A. O., Lavik, G., Schmid, M., Jorgensen, B. B., Kuenen, J. G., Damste, J. S. S., Strous, M., and Jetten, M. S. M.: Anaerobic ammonium oxidation by anammox bacteria in the Black Sea, Nature, 422, 608-611, 2003.

Lam, P. and Kuypers, M. M. M.: Microbial Nitrogen Cycling Processes in Oxygen Minimum Zones, Annual Review of Marine Science, 3, 317-345, 2011.

Lee, C.: Controls on organic carbon preservation - the use of stratified water bodies to compare rates of deomcposiiton in oxic and anoxic systems. Geochim. Cosmochim. Ac., 56, 3323-3335, 1992.

Lee, C., Murray, D. W., Barber, R. T., Buesseler, K. O., Dymond, J., Hedges, J. I., Honjo, S., Manganini, S. J., Marra, J., Moser, C., Peterson, M. L., Prell, W. L., Wakeham, S. G., and the Arabian Sea Carbon Flux Group: Particulate organic carbon fluxes: compilation of results from the 1995 US JGOFS Arabian Sea Process Study, Deep-Sea Res. Pt. II, 45, 2489-2501, 1998. the author is 'the Sea Carbon Flux Group' and I think that my reference manager cut off the word 'group'. It should stay here in the authors list. Thanks

Lee, C., Armstrong, R. A., Cochran, J. K., Engel, A., Fowler, S. W., Goutx, M., Masque, P., Miquel, J. C., Peterson, M., Tamburini, C., and Wakeham, S.: MedFlux: Investigations of particle flux in the Twilight Zone, Deep-Sea Res. Pt. II, 56, 1363-1368, 2009.

Le Moigne, F. A. C., Sanders, R. J., Villa-Alfageme, M., Martin, A. P., Pabortsava, K., Planquette, H., Morris, P. J., and Thomalla, S. J.: On the proportion of ballast versus non-ballast associated carbon export in the surface ocean, Geophys. Res. Lett., 39, 15610-15616, doi:10.1029/2012GL052980, 2012.

Le Moigne, F. A. C., Gallinari, M., Laurenceau, E., and De La Rocha, C. L.: Enhanced rates of particulate organic matter remineralization by microzooplankton are diminished by added ballast minerals, Biogeosciences, 10, 5755-5765, doi:10.5194/bg10-5755-2013, 2013.

Levin, L., Gutierrez, D., Rathburn, A., Neira, C., Sellanes, J., Munoz, P., Gallardo, V., and Salamanca, M.: Benthic processes on the Peru margin: a transect across the oxygen minimum zone during the 1997-98 El Nino, Prog. Oceanogr., 53, 1-27, 2002.

Levin, L. A., Liu, K. K., Emeis, K. C., Breitburg, D. L., Cloern, J., Deutsch, C., Giani, M., Goffart, A., Hofmann, E. E., Lachkar, Z., Limburg, K., Liu, S. M., Montes, E., Naqvi, W., Ragueneau, O., Rabouille, C., Sarkar, S. K., Swaney, D. P., Wassman, P., and Wishner, K. F.: Comparative biogeochemistry-ecosystem-human interactions on dynamic continental margins, J. Marine Syst., 141, 3-17, 2015.

Marchant, M., Hebbeln, D., Giglio, S., Coloma, C., and González, H. E.: Seasonal and interannual variability in the flux of planktic foraminifera in the Humboldt Current System off central Chile (30 S), Deep-Sea Res. Pt. II, 51, 2441-2455, 2004.

Marsay, C. M., Sanders, R. J., Hensen, S. A., Pavortsava, K., Achterberg, E. P., and Lampitt, R. S.: Attenuation of sinking particulate organic carbon flux through the 
mesopelagic ocean, P. Natl. Acad. Sci. USA, 112, 1089-1094, doi:10.1073/pnas.1415311112, 2015.

Martin, J. H., Knauer, G. A., Karl, D. M., and Broenkow, W. W.: VERTEX - Carbon cycling in the North East Pacific, Deep-Sea Res., 34, 267-285, 1987.

Matsumoto, K.: Biology-mediated temperature control on atmospheric $p \mathrm{CO}_{2}$ and ocean biogeochemistry, Geophys. Res. Lett., 34, L20605, doi:10.1029/2007GL031301, 2007.

Mayer, L. M.: Surface area control of the organic carbon accumulation in continental margin sediments, Geochim. Cosmochim. Ac., 58, 1271-1284, 1994.

McDonnell, A. M. P., Lam, P. J., Lamborg, C. H., Buesseler, K. O., Sanders, R., Riley, J. S., Marsay, C., Smith, H. E. K., Sargent, E. C., Lampitt, R. S., and Bishop, J. K. B.: The oceanographic toolbox for the collection of sinking and suspended marine particles, Prog. Oceanogr., 133, 17-31, 2015.

Meyersschulte, K. J. and Hedges, J. I.: Molecular evidence for a terrestrial component of organic matter in ocean water, Nature, 321, 61-63, 1986.

Naqvi, W. A.: Geographical extend of denitrification in the Arabian Sea in relation to some physical processes, Oceanol. Acta, 14, 281-290, 1991.

Newell, S. E., Babbin, A. R., Jayakumar, A., and Ward, B. B.: Ammonia oxidation rates and nitrification in the Arabian Sea, Global Biogeochem. Cy., 25, 1-10, doi:10.1029/2010GB003940, 2011.

Nunn, B. L., Ting, Y. S., Malmstrom, L., Tsai, Y. S., Squier, A., Goodlett, D. R., and Harvey, H. R.: The path to preservation: Using proteomics to decipher the fate of diatom proteins during microbial degradation, Limnol. Oceanogr., 55, 1790-1804, 2010.

Passow, U., and De la Rocha, C. L.: Accumulation of mineral ballast on organic aggregates, Global Biogeochem. Cy., 20, 1-7, doi:10.1029/2005GB002579, 2006.

Paulmier, A. and Ruiz-Pino, D.: Oxygen minimum zones (OMZs) in the modern ocean, Prog. Oceanogr., 80, 113-128, 2009.

Peterson, M. L., Wakeham, S. G., Lee, C., Askea, M. A., and Miquel, J. C.: Novel techniques for collection of sinking particles in the ocean and determining their settling rates, Limnol. Oceanogr.-Meth., 3, 520-532, 2005.

Piraud, M., Vianey-Saban, C., Petritis, K., Elfakir, C., Steghens, J. P., and Bouchu, D.: Ion-pairing reversed-phase liquid chromatography/electrospray ionization mass spectrometric analysis of 76 underivatized amino acids of biological interest: a new tool for the diagnosis of inherited disorders of amino acid metabolism, Rapid Commun. Mass Sp., 19, 1587-1602, 2005.

Ploug, H.: Small-scale oxygen fluxes and remineralization in sinking aggregates, Limnol. Oceanogr., 46, 1624-1631, 2001.

Ploug, H., Iversen, M. H., and Fischer, G.: Ballast, sinking velocity, and apparent diffusivity within marine snow and zooplankton fecal pellets: Implications for substrate turnover by attached bacteria, Limnol. Oceanogr., 53, 1878-1886, 2008.

Riley, J. S., Sanders, R., Marsay, C., Le Moigne, F. A. C., Achterberg, E. P., and Poulton, A. J.: The relative contribution of fast and slow sinking particles to ocean carbon export, Global Biogeochem. Cy., 26, 1026-1036, doi:10.1029/2011GB004085, 2012.

Roland, L. A., McCarthy, M. D., and Guilderson, T.: Sources of molecularly uncharacterized organic carbon in sinking particles from three ocean basins: A coupled Delta ${ }^{14} \mathrm{C}$ and delta ${ }^{13} \mathrm{C}$ approach, Mar. Chem., 111, 199-213, 2008.
Roullier, F., Berline, L., Guidi, L., Durrieu De Madron, X., Picheral, M., Sciandra, A., Pesant, S., and Stemmann, L.: Particle size distribution and estimated carbon flux across the Arabian Sea oxygen minimum zone, Biogeosciences, 11, 4541-4557, doi:10.5194/bg-11-4541-2014, 2014.

Stramma, L., Schmidtko, S., Levin, L. A., and Johnson, G. C.: Ocean oxygen minima expansions and their biological impacts, Deep-Sea Res. Pt. I, 57, 587-595, 2010.

Stramma, L., Prince, E. D., Schmidtko, S., Luo, J. G., Hoolihan, J. P., Visbeck, M., Wallace, D. W. R., Brandt, P., and Kortzinger, A.: Expansion of oxygen minimum zones may reduce available habitat for tropical pelagic fishes, Nature Climate Change, 2, 3337, 2012.

Tanoue, E., Nishiyama, S., Kamo, M., and Tsugita, A.: Bacterial membranes - possible source of a major dissolved protein in seawater, Geochim. Cosmochim. Ac., 59, 2643-2648, 1995.

Thamdrup, B., Dalsgaard, T., and Revsbech, N. P.: Widespread functional anoxia in the oxygen minimum zone of the Eastern South Pacific, Deep-Sea Res. Pt. I, 65, 36-45, 2012.

Tiano, L., Garcia-Robledo, E., Dalsgaard, T., Devol, A. H., Ward, B. B., Ulloa, O., Canfield, D. E., and Revsbech, N. P.: Oxygen distribution and aerobic respiration in the north and south eastern tropical Pacific oxygen minimum zones, Deep-Sea Res. Pt. I, 94, 173-183, 2014.

Ulloa, O., Canfield, D. E., DeLong, E. F., Letelier, R. M., and Stewart, F. J.: Microbial oceanography of anoxic oxygen minimum zones, P. Natl. Acad. Sci. USA, 109, 15996-16003, 2012.

Vandewiele, S., Cowie, G., Soetaert, K., and Middelburg, J. J.: Amino acid biogeochemistry and organic matter degradation state across the Pakistan margin oxygen minimum zone, DeepSea Res. Pt. II, 56, 376-392, 2009.

Van Mooy, B. A. S., Keil, R. G., and Devol, A. H.: Impact of suboxia on sinking particulate organic carbon: Enhanced carbon flux and preferential degradation of amino acids via denitrification, Geochim. Cosmochim. Ac., 66, 457-465, 2002.

Wang, D. Z., Dong, H. P., Xie, Z. X., Dai, M. H., and Hong, H. S.: Metaproteomic characterization of dissolved organic matter in the water column of the South China Sea, Limnol. Oceanogr., 56, 1641-1652, 2011.

Ward, B. B., Tuit, C. B., Jayakumar, A., Rich, J. J., Moffett, J., and Naqvi, S. W. A.: Organic carbon, and not copper, controls denitrification in oxygen minimum zones of the ocean, Deep-Sea Res. Pt. I, 55, 1672-1683, 2008.

Ward, B. B., Devol, A. H., Rich, J. J., Chang, B. X., Bulow, S. E., Naik, H., Pratihary, A., and Jayakumar, A.: Denitrification as the dominant nitrogen loss process in the Arabian Sea, Nature, 461, 78-81, 2009.

Wishner, K. F., Gelfman, C., Gowing, M. M., Outram, D. M., Rapien, M., and Williams, R. L.: Vertical zonation and distributions of calanoid copepods through the lower oxycline of the Arabian Sea oxygen minimum zone, Prog. Oceanogr., 78, 163191, 2008.

Wishner, K. F., Outram, D. M., Seibel, B. A., Daly, K. L., and Williams, R. L.: Zooplankton in the eastern tropical north Pacific: Boundary effects of oxygen minimum zone expansion, Deep-Sea Res. Pt. I, 79, 122-140, 2013. 